\title{
Results of the Radius Factor Stability Assessment Method for Design and Pillar Extraction at the Conqueror Mine, St Ives Gold Mine
}

\author{
P.G. Andrews Gold Fields Australia Pty Ltd, Australia \\ B.J. Barsanti Gold Fields Australia Pty Ltd, Australia
}

\begin{abstract}
A reliable stability assessment for stoping is critical at the design stage of mining and the Conqueror mine at Gold Fields' St Ives operations is no exception. The mining method at Conqueror was longhole open stoping with diminishing rib to island pillars.
\end{abstract}

The Mathews Stability Graph Method (SG) was initially used to assess the Conqueror primary stopes but proved unwieldily with the onset of the extraction of the secondary stopes from rib to island pillars. The St Ives Geotechnical Department therefore had to search for an alternative stability assessment method.

A Canadian stability method, Radius Factor (Milne, 1996), was investigated and subsequently trialled. Whilst Hydraulic Radius as considered in the Stability Graph method is based on boundary geometry (length $x$ width), the Radius Factor method is based on surface geometry. Two new terms were introduced to site personnel, Radius Factor $(R F)$ is related to the overall stability and maximum deformation of a surface and Effective Radius Factor (ERF) is related to the local stability and deformation of a point on the stope surface.

The method was trialled firstly as a tool to back analyse old stoping areas. Back analysis showed the method to be effective for determining maximum stable spans. The method was then used as a design tool for determining maximum spans and pillar placement in the mine design.

The Radius Factor method was continually calibrated to actual mine results over the life of the mine. This calibration enabled stope geometry and sequencing changes to incorporate best geotechnical practice into the mine extraction sequence. As a result the St Ives geotechnical and mining teams were able to safely extend two stope lengths and extract one central pillar resulting in an extra $404 \mathrm{~kg}$.

\section{Introduction}

The St Ives Gold mine is located on Lake Lefroy, approximately $60 \mathrm{~km}$ south of Kalgoorlie. The site at present comprises three underground operations and four active open pits. It produces approximately $484 \mathrm{~kg}$ of gold annually.

The Conqueror mine was one of three mines in the Leviathan Underground Complex which produced at rates of between 75,000 $\mathrm{t}$ and 100,000 $\mathrm{t}$ per month. The Conqueror series of stopes at Leviathan had 14 separate stopes from $20-135 \mathrm{~m}$ long. Heights of the stopes vary from $15-45 \mathrm{~m}$ and $20 \mathrm{~m}$ wide.

During the Conqueror mine life it was decided to extend the strike spans of two stopes based on geotechnical performance. Towards the end of mine life the decision was made to extract the 2503 island pillar.

\section{Site history}

The Leviathan Underground Complex was previously known as the Victory mine. Open pit gold mining commenced at Victory mine by WMC Resources in 1980 with subsequent underground development commencing in 1981. The Victory underground was mined in conjunction with open pit mining of the adjacent Defiance pit from 1985. All underground mining ceased in 1998. Mining of several open pits in the immediate area, including Victory North, Britannia, Sirius and Victory North Extended, was completed by 1994.

The primary mining methods at Victory underground mine included mechanised mining by room and pillar, benching, flat backing, pillar stripping and longhole open stoping (LHOS). Most large (>40 m high spans) 
LHOS voids are in the lower levels of Victory with most of the upper level void areas being extensive room and pillar. The Defiance pit mined through room and pillar workings which are now exposed in the east wall of the pit. Victory and North Victory pits broke through into vertical sediment lodes. By 1998 there was an estimated $90 \mathrm{~km}$ of lateral jumbo development during the mine life.

In 2001, St Ives Gold mine was brought by Gold Fields which started dewatering the Leviathan Underground Complex in 2002. The Leviathan Underground Complex currently consists of the three underground mines; Sirius/Britannia, East Repulse and Conqueror, of which one is currently active and the other two are undergoing further exploration.

Recently open pit mining has recommenced in the Defiance and Victory pits, now called the Leviathan pit. This pit will mine through more room and pillar workings and other larger underground voids.

In total the Victory/Leviathan Complex has produced $26.9 \mathrm{Mt}$ of ore for $86,779 \mathrm{~kg}$. The open pits have provided $13.9 \mathrm{Mt}$ for $27,682 \mathrm{~kg}$ with underground mines providing $13 \mathrm{Mt}$ for $59,097 \mathrm{~kg}$. This Victory/Leviathan Complex has been the major gold producer in the St Ives field total of over $279,931 \mathrm{~kg}$ since 1980.

\section{Geology}

Gold mineralisation is hosted in two sub-parallel, south-dipping, $\left(25^{\circ}\right)$ reverse shear zones, namely the 33 and 32 Surfaces. Within the shears, brecciated quartz/carbonate lodes have developed with a south-west dipping orientation $\left(20^{\circ} / 225^{\circ}\right)$, the highest grades are consistently associated with these lodes.

Both shear zones have developed thickened south-west plunging sigmoidal/dilational shoots through more brittle lithologies such as the granophyric zone of the Defiance Dolerite. Within theses shoots, multiple quartz/carbonate breccia lodes have developed in a stacked, en-echelon geometry, resulting in thick, high grade ore intersections.

The location and orientation of mineralisation is controlled by the intersection of a low-angle shear zone (D5 shear zone) with the southwest striking Defiance Dolerite and Kapai Slate. The D5 shear zone is generally tightly healed although gypsum infill has been noted in the upper levels of the mine. The D5 shear zone undulates over the mineralised zone. To the north the D5 forms the actual hangingwall contact, but as the mineralised zone dips further south the D5 moves away from the hangingwall contact and undulates between $10 \mathrm{~m}$ and $20 \mathrm{~m}$ into the hangingwall of the mineralised zone.

\section{Stope design}

The Conqueror design consisted of 14 stopes varying from $20-135 \mathrm{~m}$ long and 15-45 $\mathrm{m}$ in height. All stopes were $20 \mathrm{~m}$ wide. The stopes strike east-west with accesses staggered down dip. The mining method consisted of primary longhole open stoping (LHOS) with diminishing rib to island pillars in the secondary stopes (Barsanti et al., 2006).

Pillars were designed into the secondary stopes with the exception of the 2001 stope which has a low grade zone which was left as an additional pillar. All pillars are $20 \mathrm{~m}$ wide $\mathrm{x} 20 \mathrm{~m}$ long and of varying height. The width to height ratios vary from 1:2.25 in the larger stopes to 1:0.75 in the smaller stopes to the south.

The four stopes with intermediate access were stoped using a combination of short up holes from the lower levels along with up holes and long down holes from the intermediate level. During extraction of the stopes, a trial of retreating the undercut at a greater rate than the overcut was undertaken, although a majority of the stopes used a simultaneous retreat of the overcut and undercut. 


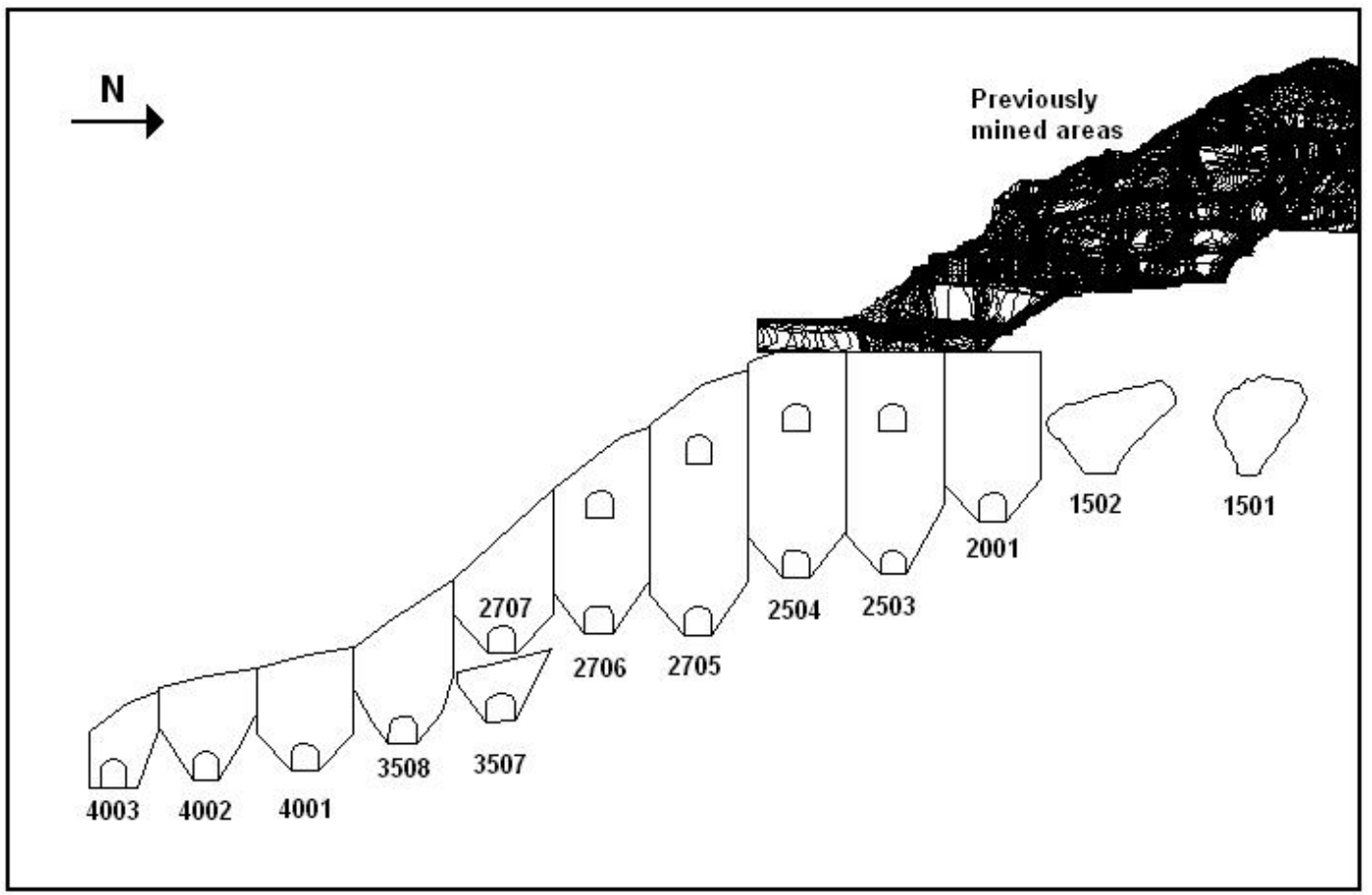

Figure 1 South-North cross section of the original Conqueror stope design

Once all the stopes were extracted an open span down dip of $300 \mathrm{~m}$ was exposed. This void extends from the old workings ( $280 \mathrm{~m}$ below surface) to the end of the current stoping area (450 m B.S.).

The stoping sequence implemented was not a conventional method of extraction, but the extraction of two or more primary stopes commenced and before they were completed the extraction of the secondary stope commenced.

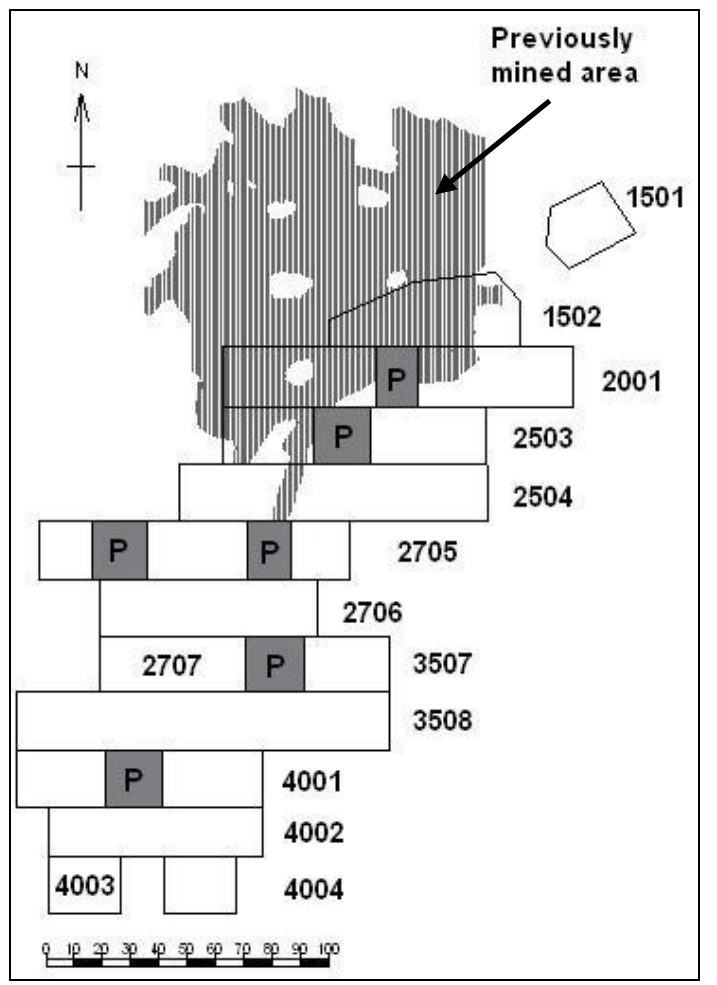

Figure 2 Plan view of the original Conqueror stope and pillar design with old workings overlayed 


\section{Rock mass and stability assessments}

\subsection{Quantitative description of the rock mass}

The rock mass was classified using the International Society for Rock Mechanics (ISRM) suggested system. The system allows various geometric and strength parameters to be characterised. These parameters have been tabulated below.

Table 1 Characterisation of joint sets in Conqueror

\begin{tabular}{lcccc}
\hline & Joint Set 1 & Joint Set 2 & Joint Set 3 & Joint Set 4 \\
\hline Dip & $24^{\circ}$ & $90^{\circ}$ & $74^{\circ}$ & $69^{\circ}$ \\
Dip direction & $180^{\circ}$ & $358^{\circ}$ & $303^{\circ}$ & $138^{\circ}$ \\
Total spacing & Very closely & Very widely & Moderately & Moderately \\
& spaced & spaced & widely spaced & widely spaced \\
Persistence & High & Very high & Low & Low \\
Roughness & Smooth/planar & Rough/planar & Rough/planar & Rough/planar \\
Wall strength & $280 \mathrm{MPa}$ & $280 \mathrm{MPa}$ & $280 \mathrm{MPa}$ & $280 \mathrm{MPa}$ \\
Aperture & Tight & Very tight & Very tight & Very tight \\
Filling & Talc/gypsum & Quartz/carbonate & Quartz/carbonate & Quartz/carbonate \\
Fill strength & $<10 \mathrm{MPa}$ & $60-80 \mathrm{MPa}$ & $60-80 \mathrm{MPa}$ & $60-80 \mathrm{MPa}$ \\
Seepage & Dry & Dry & Dry & Dry \\
Comments & D5 shear & Dominant set & Steep north-west & Steep south-east \\
\hline
\end{tabular}

\subsection{Rock mass classification}

The Q system (Barton et al., 1974) is used across all underground sites at St Ives mine for rock mass classification purposes. The Q' value (Barton et al., 1974) has two components; RQD/Jn is a measure of average block size for a jointed rock mass and $\mathrm{Jr} / \mathrm{Ja}$ is a measure of joint surface strength and stiffness. The Q' value is calculated using Equation (1) (Barton et al., 1974):

$$
Q^{\prime}=\frac{R Q D}{J n} \times \frac{J r}{J a}
$$

\subsection{Mathews stability graph method}

The Stability Graph concept is a means of empirically predicting the stability of large unsupported openings and was conceived by Ken Mathews and co-workers (Mathews et al., 1981). It has proved to be a useful design tool for hanging walls of non-entry stopes. The original concept has been calibrated by Potvin (1989) and modified by Nickson (1992).

The main idea was to plot a rating, the N' number, against the hydraulic radii of a stope. To determine this N' number, the modified Q' number, Barton et al. (1974), of the rock mass is multiplied by a stress factor (A), a structural orientation factor relative to the hanging wall (B), and a gravity factor (C). This allowed a weighting to be given for each of these factors dependant on their influence in the stability assessment. The $\mathrm{B}$ values ranged from 0.26 to 0.29 whilst $\mathrm{C}$ values ranged from 2.5 to 3.0 depending on the dip of the hangingwall of each stope. Table 2 shows the mean value of these factors.

The Hydraulic Radii is then calculated by dividing the area of the stope by its perimeter. Hydraulic radius is only suited to two-dimensional rectangular surfaces. Only the primary stopes could be analysed using this method. Complex stope geometries when island pillars are created cannot easily be incorporated into the system (Milne and Pakalnis, 1997). 
Table 2 Rock mass classification and stability graph parameters

\begin{tabular}{lccccc}
\hline & Q' & A & B & C & N' \\
\hline Mean & 15.8 & 0.95 & 0.28 & 2.6 & 10.9 \\
50th percentile & 12.1 & 0.95 & 0.28 & 2.6 & 8.4 \\
25th percentile & 9.3 & 0.95 & 0.28 & 2.6 & 6.4 \\
75th percentile & 23.2 & 0.95 & 0.28 & 2.6 & 16.0 \\
\hline
\end{tabular}

\subsection{Effective radius factor}

Due to the complexity of the orebody geometry and stope design, the stability analysis was carried out using the Radius Factor (RF) (Milne, 1996) method. The RF method is based on the deformation of complex geometries. The effective radius factor (ERF) measures the distance from a point located on the backs to the nearest abutment, pillar or brow. These measurements are taken at a specific radial angular interval, such as every $5^{\circ}$. ERF will have a maximum value towards the centre of the surface, where it is equivalent to HR, and decreasing values towards the edges. The maximum ERF value calculated for a surface is defined as the RF value. This method allows the effect of pillars to be taken into account in relation to hanging wall stability and can be used with irregular shaped backs, brows and intersections (Pakalnis et al., 1996). The maximum ERF number obtained can then be used on the Mathews Stability Graph in place of the hydraulic radius value to create the equivalent of the Mathews Stability Chart (Milne, 1997). The Effective Radius Factor is calculated using Equation (2):

$$
R F=\frac{0.5}{\frac{1}{n} \sum_{\theta=1}^{n} \frac{1}{r_{\theta}}}
$$

where:



$n=$ number of measurements and $r_{\theta}=$ distance to abutment, pillar or brow.
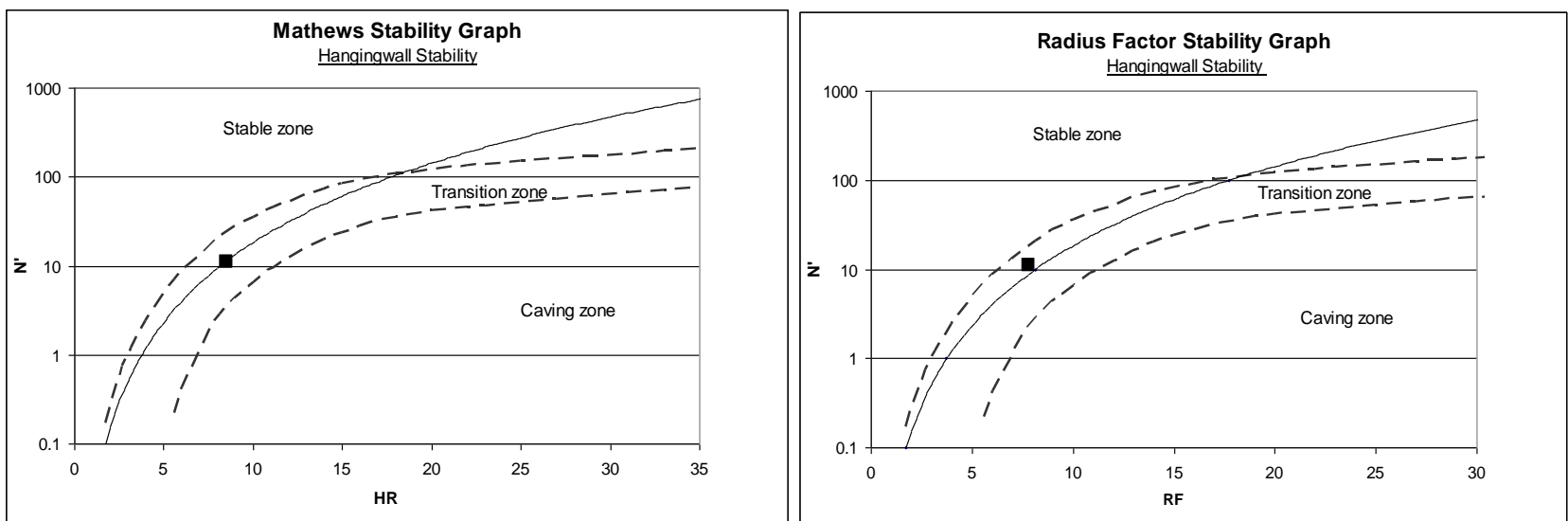

Figure 3 Stope 2504 stope stability graphs - Mathews versus ERF

ERF values can then be calculated on a grid pattern across the entire surface of the span to be analysed. Once multiple ERF values are obtained the values can be contoured. Contoured ERF values can be produced in two and three dimensions. For the stability assessment of Conqueror the ERF values were contoured using a Kriging method on the Surfer® software package. 
The ability to contour the ERF values and overlay them onto a 2D or 3D representation of the span allows for much greater visual appreciation of areas of possible instability. The whole mining sequence can be viewed, step by step from start to finish. Using this sequential visual display it was easy to determine the mining sequence that allows for the greatest hangingwall stability for the life of mining.

\section{$6 \quad$ Stress analysis}

Numerical modelling is also used to assess hangingwall stability with the help of the program, Map3D®. This program was used as a stability assessment tool and assisted with back analysing previously mined stopes.

As part of the Mathews Stability method the effects of mining induced stress are considered. The strength of the dolerite at Leviathan is at least seven times greater than the induced stresses. Recent acoustic emission testing was carried out at Conqueror from a depth of $324 \mathrm{~m}$ to estimate the in situ stress and produced the results as shown in Table 3.

Table 3 Stress values for the Conqueror mine

\begin{tabular}{lcccc}
\hline & Value $(\mathrm{MPa})$ & Bearing $\left(^{\circ}\right)$ & Plunge $\left(^{\circ}\right)$ & MPa per Meter \\
\hline Sigma 1 & 25.9 & 288 & 03 & 0.079 \\
Sigma 2 & 21.9 & 197 & 28 & 0.068 \\
Sigma 3 & 8.0 & 023 & 62 & 0.025 \\
\hline
\end{tabular}

The maximum induced stresses at the southern end of the mine (which is approximately $425 \mathrm{~m}$ ) are:

- $\quad$ Sigma $1=33.9 \mathrm{MPa}$ (sub-horizontal east-west).

- $\quad$ Sigma $2=28.8 \mathrm{MPa}$ (shallow southerly dip).

- $\quad$ Sigma $3=10.5 \mathrm{MPa}$ (steep northerly dip).

The direction of sigma 1 is oriented along strike of the D5 shear zone while sigma 2 is oriented along the plunge of the ore and sigma 3 is normal to the D5 shear.

\section{$7 \quad$ Results}

\subsection{Back analysis}

As part of the geotechnical assessment of the stoping areas, a back analysis of the old WMC workings in Conqueror was done using the ERF method to provide the previous span stability limitations. Conqueror stoping levels mined by WMC were the one and two levels. WMC then mined levels three through to six using a combination of jumbo development and stripping with long hole open stoping joining each of the levels creating a room and pillar layout. The ERF back analysis was done on levels three to six as these were deemed similar to how Conqueror was going to be mined.

Old plans and survey records were examined and it was determined that the WMC design did not exceed an ERF value of greater than $13 \mathrm{~m}$ (Figure 4).

The back analysis also showed that there was a pillar failure between levels four and five and after this an ERF value of $22 \mathrm{~m}$ was created (Figure 4).

In conversations with the geotechnical engineer at the time, it was revealed that the pillar was determined to have failed due to a lack of confinement on the joints which allowed the pillar to unravel. When the pillar had unravelled sufficiently, the talc/gypsum infill of the D5 could not support the weight of the rock mass and the D5 shear failed in tension under gravity creating a back failure. 



Figure 4 Contoured ERF back analysis of the old Conqueror workings before and after the pillar failure 


\subsection{Mining results}

\subsubsection{Pre-June 2006}

The 1502 stope was the first stope extracted. This stope was $64 \mathrm{~m}$ in length and no geotechnical issues arose. Stope boundaries were within $0.2 \mathrm{~m}$ of design in the hangingwall and there was no fall off from the walls. Figure 5 shows the contoured ERF values for this mining period.

As the 1502 stope was being completed, the 2001 stope began. This also was completed without any geotechnical issues arising. A planned $20 \mathrm{~m}$ square (width by length) pillar was left in the 2001 stope as per the original mine design. This pillar placement coincided with a large barren zone. These two stopes created an ERF greater than $12 \mathrm{~m}$ at the eastern ends of the stopes.

The whole of the 2504 stope was mined in conjunction with the 2001 stope and the strike length of this stope exceeded $100 \mathrm{~m}$. There was no dilution, and overbreak of the whole stope averaged $0.6 \mathrm{~m}$ depth or $1 \%$.

The 2503 stope was extracted back to the first planned pillar. A north-south span of $60 \mathrm{~m}$ was created from the 2001 to 2504 stope. This created an ERF contour greater than $12 \mathrm{~m}$ across the backs in the 2503/2504 stoping area. The visual observations from underground combined with the CMS data revealed no overbreak or fretting in the hangingwall.

The 2503 and 2001 stope broke into old WMC stopes workings which increased the stope height by $20 \mathrm{~m}$ at the western end. Some water and waste rock fell from these voids as they had previously been used as a waste rock stockpile. No other geotechnical issues were noticed.

The 2706 and 2707 stopes commenced and were extracted simultaneously over a two month period. The 2707 stope was completed in May with final strike length of $75 \mathrm{~m}$. An ERF contour greater than $8 \mathrm{~m}$ was reached across the backs of the 2706/2707 stopes. The observations from underground revealed no visible overbreak or fretting in the hangingwall.



Figure 5 ERF contours of mining prior to June 2006 


\subsubsection{June to August 2006}

The 2503 stope was extracted back from the first planned pillar. An ERF contour of greater than $8 \mathrm{~m}$ was then reached in the 2001/2503/2504 stoping area, as shown in Figure 6. The visual observations from underground combined with the CMS data revealed no overbreak or fretting in the hangingwall.

The 2706 stope was extracted a further $35 \mathrm{~m}$ until completion. An ERF contour greater than $12 \mathrm{~m}$ was reached in the 2001/2503 stoping area. Minor fretting in the 2706 and 2707 area occurred due to the hangingwall geometry and interaction with the D5 shear and was not span related.

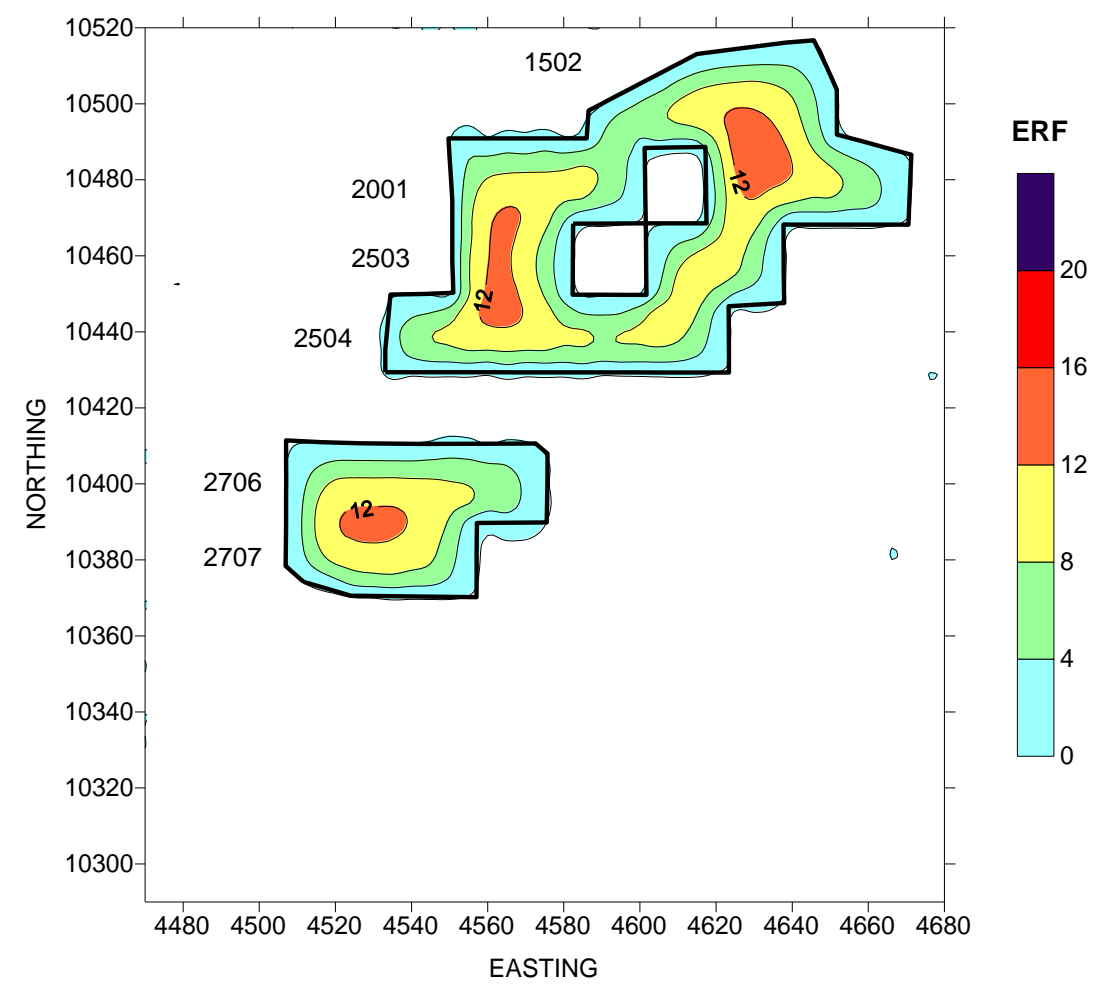

Figure 6 ERF contours of mining between June and August 2006

\subsubsection{September to December 2006}

The extraction of the 2705, 3507, 4001, 4002 and 4003 stopes all started between September and December 2006. Contoured ERF values are shown in Figure 7.

The 4001 stope was extracted to a strike length of $10 \mathrm{~m}$ and then the 4002 stope was retreated back $10 \mathrm{~m}$. The hangingwall between the two stopes started to unravel to the D5 shear. The first stope blast in the 4003 stope was then fired and the hangingwall failure propagated across all three stopes, breaking back to the D5. The majority of the failure was occurred above the 4002 stope, which resulted in the dilution of the broken ore stocks that were still in the stope. The true thickness of the initial failure above the 4002 was approximately $3.5 \mathrm{~m}$. Initial failure across 4001, 4002 and $4003-8864 \mathrm{t}$ at $0.524 \mathrm{~g} / \mathrm{t}$. The last half of 4002 stope was then left as a temporary pillar whilst the 4003 was mined. The 4003 stope was further extracted to $20 \mathrm{~m}$ with some hangingwall failure occurring above the stope. A maximum ERF of just over $4.0 \mathrm{~m}$ was reached (Figure 8).

The 2705 stope was retreated to a strike length of $16 \mathrm{~m}$ which was $5 \mathrm{~m}$ beyond the start of the 2504 stope. Minimal overbreak occurred at this stage. The next stope blast of $15 \mathrm{~m}$ strike length in the 2705 was then fired. This firing caused a large scale failure. This large hangingwall failure $(\sim 11,000 \mathrm{t})$ began in the hangingwall above the 2706/2707 stopes. It is believed the failure occurred from the hangingwall of the 2706 or on the hangingwall step down from 2706 to the 2707 . The vertical thickness of failure above the 2707 was $\approx 6.7 \mathrm{~m}$ and $\approx 3.5 \mathrm{~m}$ above the 2706 . The RF value in the area of the failure was just over $12 \mathrm{~m}$ (Figure 7). 
The failure mechanism of the hangingwall was a tensional-gravity failure on the D5 shear (Figure 8). The talc/gypsum infill of the D5 could not support the weight of the rock mass between the hangingwall and the D5 shear failed in tension under gravity after the extraction of stopes in the surrounding area.



Figure 7 ERF contours of mining between September and December 2006

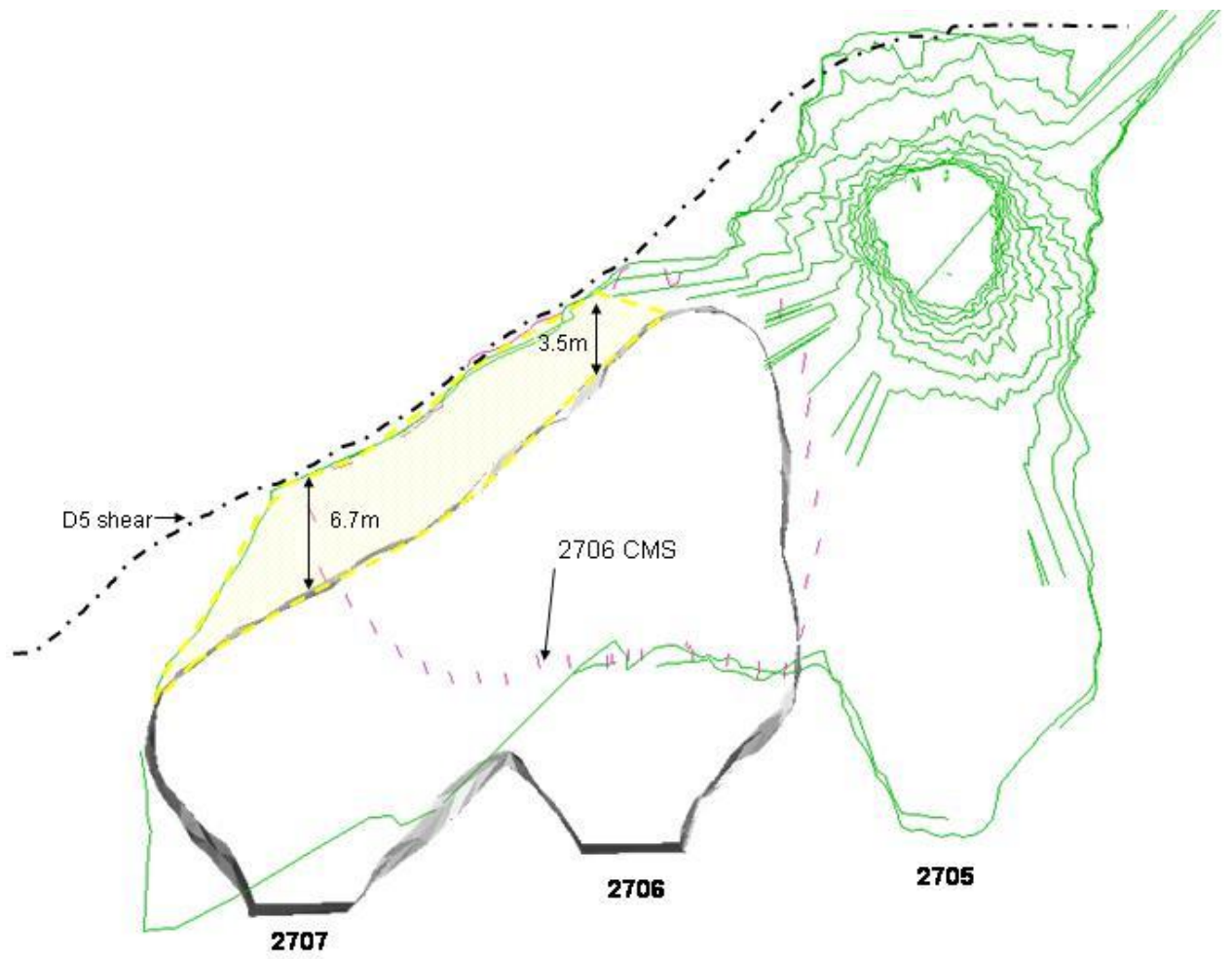

Figure 8 Cross section of the hangingwall failure above the 2707 to 2705 stopes 


\subsubsection{January to June 2007}

The extraction of the 3508 stope commenced in January. The geotechnical department recommended leaving a 5-6 m wide rib pillar along the right wall of the 3508 stope, to prevent the two failures (4002 and 2706) from propagating towards each other and potentially joining. The 3508 stope was retreated the full $118 \mathrm{~m}$ along strike. No continuance of the failure and minimal overbreak was observed.

By March 2007 the 2705 stope had retreated to a strike length of $40 \mathrm{~m}$ with minimal new overbreak. During a firing in April the failure above the 2706/2707 arched a further $12 \mathrm{~m}$ (vertical height) above the initial failure from December 2006. This equated to another 30,675 t at $0.18 \mathrm{~g} / \mathrm{t}$. An ERF value greater than $16 \mathrm{~m}$ was created across the backs of the 2705/2706/2707 stopes.

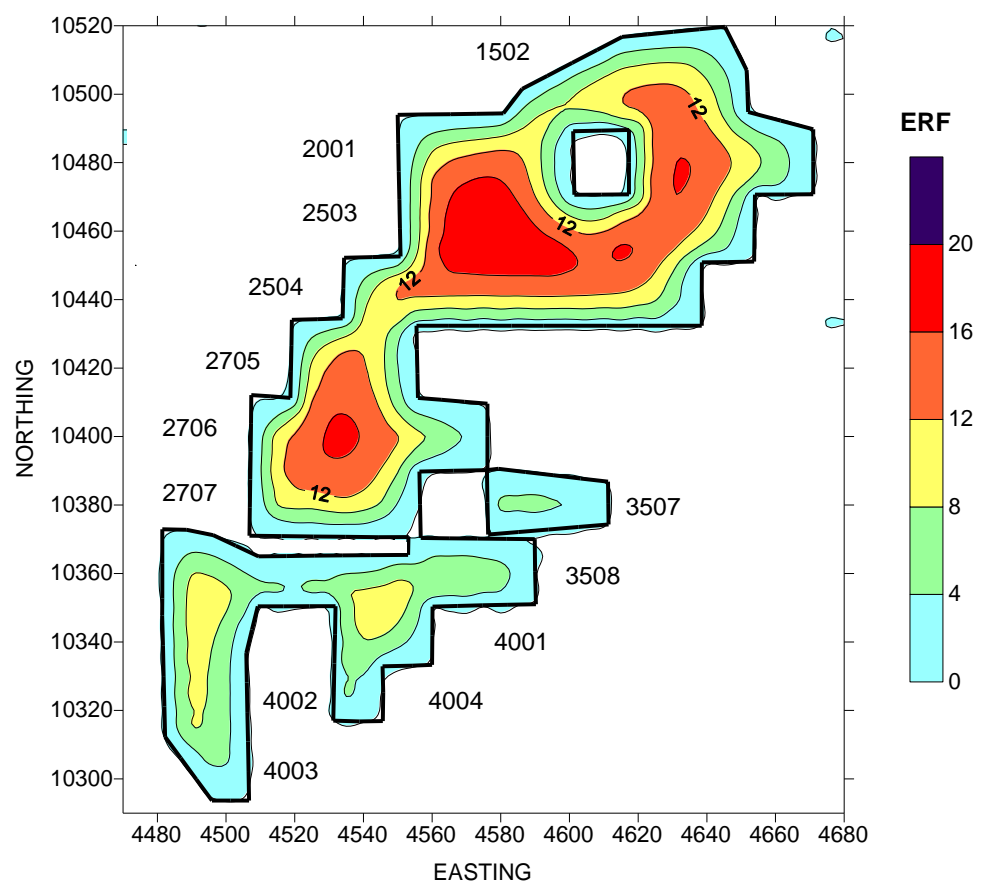

Figure 9 ERF contours of mining between January and June 2007

The 4001 and 4003 stopes were both retreated to a strike length of $35 \mathrm{~m}$. The failure propagated further and arched higher above the initial 4002 opening. This totalled $5912 \mathrm{t}$ at $0.529 \mathrm{~g} / \mathrm{t}$. The rest of the 4002 stope was then extracted leaving a $1.5 \mathrm{~m}$ pillar in both walls and in the backs. The resultant stope did not break back to the D5 and no dilution occurred. The pillar was left in the 4001 stoping area as originally intended. The ERF in the western section of the 4001/4002/4003 stope was greater than $8 \mathrm{~m}$ (Figure 9).

The 4001 stope 2 (east) and 4004 stopes were commenced in May. The initial two firings in the 4004 suffered from underbreak and some overbreak.

\subsubsection{Pillar recovery investigation}

It was initially proposed by the mine management that pillar extraction scenarios were to be investigated by the site geotechnical engineers. The possible scenarios looked at were; the 2503 pillar extraction, extending the 2503 stope by up to $30 \mathrm{~m}$, and extending the 2705 stope by up to $35 \mathrm{~m}$.

By utilising the ERF data as an investigative tool, it was decided that the 2503 pillar could be removed with little risk of hangingwall dilution.

The 2503 island pillar was first accessed by developing a drive into the draw pillar between the 2503 and 2001 stopes. Due to the fractured nature of the surrounding rock and the potential for blast damage extra ground support in the form of $50 \mathrm{~mm}$ fibrecrete and cable bolts were installed.

Production holes were drilled from the drive into the pillar. The first half of the pillar to be fired was the half closest to the access. There were collar lengths between $10 \mathrm{~m}$ and $15 \mathrm{~m}$ to allow safe re-entry in to the drive. Once charged with emulsion, these holes were padded and then grouted. Twelve (12) hours later the first half 
of the pillar was fired. The backs of the access were undamaged and the stope had no overbreak. The second firing was then taken. This also worked well and no overbreak or dilution observed in both CMS and visual observations. This total amount of ore from this pillar extraction equated to $21,440 \mathrm{t}$ at $4.44 \mathrm{~g} / \mathrm{t}$ for $95 \mathrm{~kg}$. An ERF contour of greater than $16 \mathrm{~m}$ was created across the backs of the 2001/2503/2504 stopes (Figure 9).

It was also deemed possible that the stope extensions in the 2503 and 2705 could be started on the provision that if hangingwall failure was observed that stoping would discontinue. The proposed extension was $30 \mathrm{~m}$ in the 2503 stope and $25 \mathrm{~m}$ in the 2705 stope. The total extra ore that could possibly be produced by these scenarios was $86,591 \mathrm{t}$ at $4.68 \mathrm{~g} / \mathrm{t}$ for $404 \mathrm{~kg}$.

\subsubsection{June to September 2007}

The 4001 stope was completed. The 4001 stope 2 had a failure in the hangingwall which initially started when the stope geometry changed. The stope backs dropped in height by $4.5 \mathrm{~m}$. Total volume of failure was $4447 \mathrm{t}$ at $0.263 \mathrm{~g} / \mathrm{t}$.

The 4004 stope was started and completed in this time, with no overbreak noted. Approx. $1.3 \mathrm{~m}$ of ore was left behind on the hangingwall.

The 2705 stope was continued with a small change to the geometry of the hangingwall. The 2705 stope was retreated to a strike length of $55 \mathrm{~m}$ with less than $2 \mathrm{~m}$ of overbreak from the hangingwall. This equated to an extension of the stope of $15 \mathrm{~m}$ over original design. The stope was not extended any further than this due to a change in the ore model grade. The total amount of failed material into the 2706/2707 stopes was $41,675 \mathrm{t}$ at $0.19 \mathrm{~g} / \mathrm{t}$.

The 2503 stope was extended by $20 \mathrm{~m}$. No overbreak was observed and the 2503 stope was extended by a further $10 \mathrm{~m}$. The hangingwall of the completed 2001 stope started to fail due to the change in geometry. In this area a maximum ERF of over $20 \mathrm{~m}$ was determined after this additional mining (Figure 10).

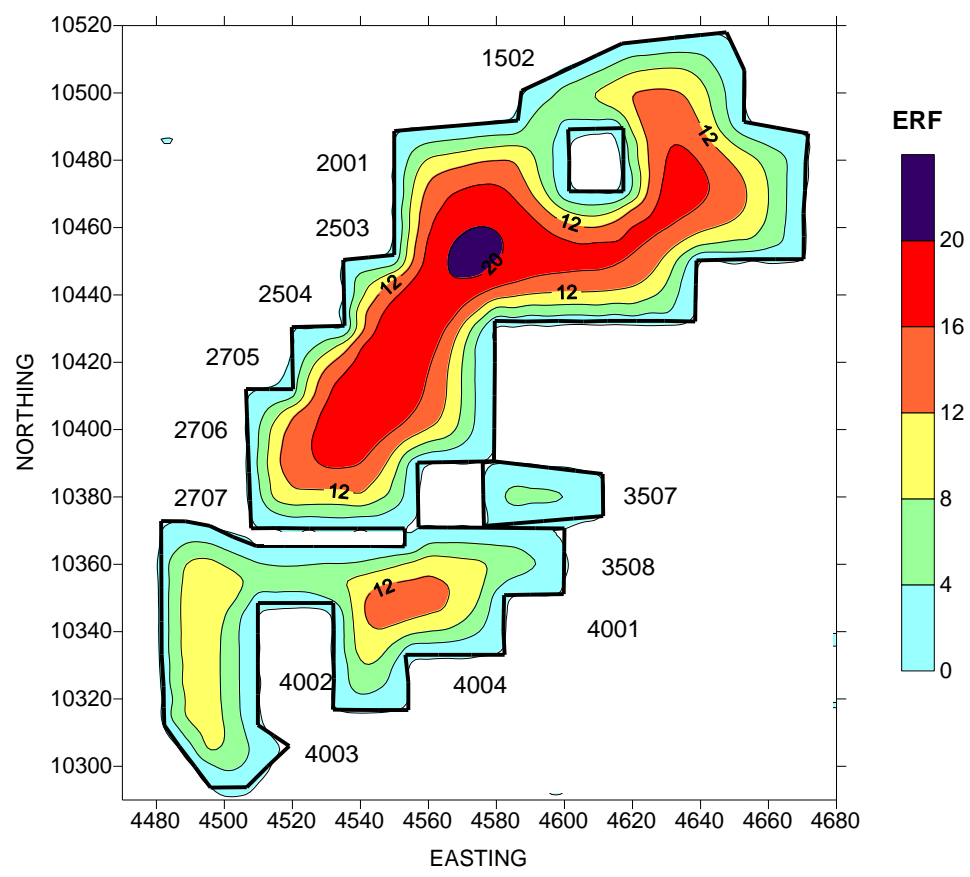

Figure 10 ERF contours of mining between June and September 2007

\subsubsection{Total mining results}

To assess the performance of the Conqueror stopes, the Equivalent Linear Overbreak/Slough or ELOS method was used (Clark, 1997). The ELOS parameter is an alternative way of expressing the volumetric measurement $\left(\mathrm{m}^{3}\right)$ overbreak/slough. It converts the true volumetric measurement into an average depth of slough or failure over the entire stope surface. A schematic describing this term and its method of calculation is shown in Figure 11. The attractiveness of this term is that its meaning from a dilution point view is more readily apparent than a volumetric measurement. 


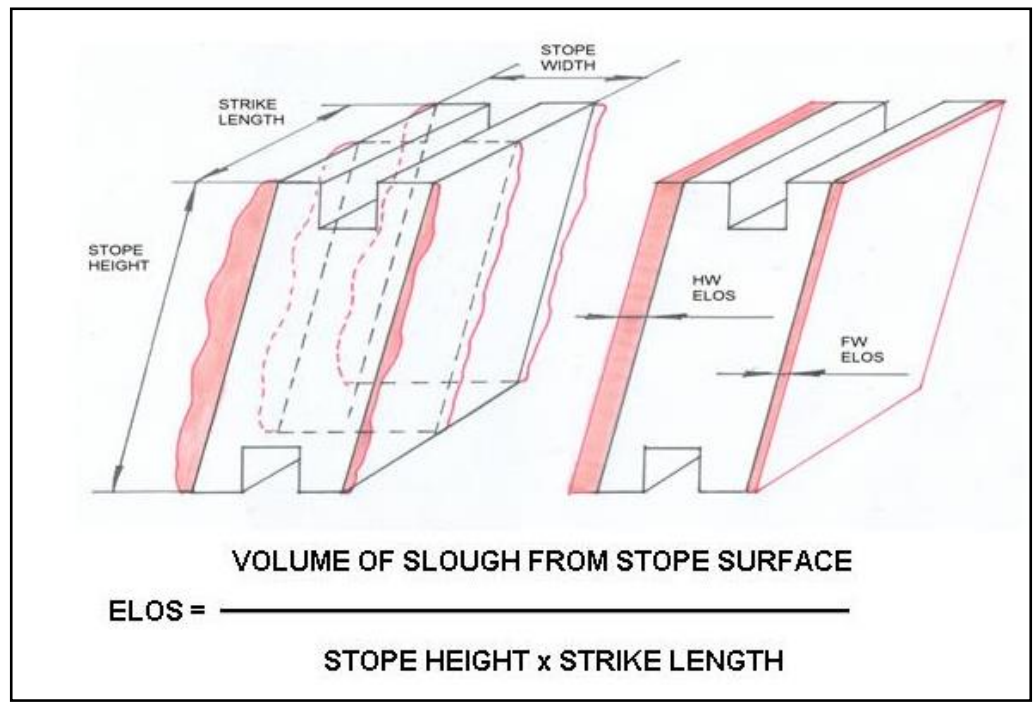

Figure 11 ELOS determination and calculation schematic (Clark, 1997)

To determine the volumetric overbreak or unmined ore in a stope a Cavity Monitoring System (CMS) survey of the stope is required. This allows the determination of volumes for overbreak/slough and underbreak from open stope surfaces, and permits a qualitative analysis of stope stability.

The stope is then cut into $2 \mathrm{~m}$ thick sections and the area of overbreak or underbreak in each section is calculated. This area is then multiplied by the thickness of each section to determine the volume. All sections are then converted to ELOS values and then averaged.

Knowing the grade of the stope and then using design values versus actual values, percentages for dilution, unmined ore, grade, and kilograms can be determined. These values are shown in Table 4.

Table 4 Mine performance parameters for the Conqueror stopes

\begin{tabular}{lccccc}
\hline Stope & ELOS HW $(\mathrm{m})$ & \% Dilution & \% Unmined Ore & \% Grade & \% Kg \\
\hline 1502 & 0.2 & 11.0 & 0.0 & 96 & 100 \\
1504 & 0.7 & 4.0 & 2.3 & 98 & 99 \\
2503 & 0.5 & 3.0 & 0.0 & 98 & 99 \\
2504 & 0.6 & 4.0 & 1.6 & 97 & 98 \\
2705 & 2.6 & 7.0 & 0.1 & 93 & 100 \\
2706 & 0.0 & 0.0 & 3.8 & 100 & 96 \\
2707 & 0.1 & 0.5 & 5.8 & 99 & 94 \\
$3705 \mathrm{~A}$ & 0.0 & 0.3 & 1.4 & 100 & 99 \\
$3705 \mathrm{~B}$ & 0.1 & 2.0 & 12.3 & 98 & 89 \\
3508 & 0.4 & 2.5 & 2.3 & 97 & 98 \\
4001 & 3.4 & 23.0 & 3.8 & 78 & 96 \\
4002 & 3.7 & 25.3 & 3.9 & 78 & 98 \\
4003 & 1.1 & 28.5 & 0.0 & 81 & 99 \\
4004 & 0.5 & 10.0 & 7.5 & 91 & 92 \\
Average & 1.0 & 8.7 & 3.2 & 93.1 & 96.9 \\
\hline
\end{tabular}


These mining performance parameters are based solely on difference between design and CMS values. Actual physical values based on trucking, bogging and milling are shown below in Table 5.

Table 5 Mine physical performance values for the Conqueror stopes

\begin{tabular}{lccc}
\hline & Tonnes & Grade $(\mathrm{g} / \mathrm{t})$ & $\mathrm{Kg}$ \\
\hline Design with pillars & $1,142,360$ & 4.42 & 5046 \\
Actual with pillars & $1,199,500$ & 4.11 & 4919 \\
Actual after pillars extracted & $1,293,440$ & 4.14 & 5363 \\
Physical difference & 151,080 & -0.27 & 317 \\
Percentage difference & $+13.23 \%$ & $-6.13 \%$ & $+6.28 \%$ \\
\hline
\end{tabular}

The proposed extraction ratio before pillar extraction and extension was $90 \%$. After the extraction of the 2503 pillar and the stope extensions in the 2503 and 2705 the extraction ratio achieved was $94.8 \%$

\section{Conclusion}

Since the inception of ERF as a geotechnical tool for stability assessments during the design phase, it has provided St Ives an effective visual display of potential stope stability. The ability to visualise stope stability in $2 \mathrm{D}$ or $3 \mathrm{D}$ allows for easier modifications to the stoping sequence and changes in geometry.

One of the major changes ERF has contributed was the change in the Conqueror stoping sequence. Sequence iterations using ERF as the controlling factor allowed the 2705 stope to be brought forward in sequence. This change enabled higher production rates whilst still maintaining hangingwall stability. It has also provided confidence in that by extracting the 3508 stope last, that hangingwall stability was maintained throughout the extraction sequence.

Back analysis during stoping using ERF methodology allowed the extraction of the 2503 pillar and extensions to two other stopes. This allowed an extra $93,940 \mathrm{t}$ at $4.58 \mathrm{~g} / \mathrm{t}$ to be mined for a further $430 \mathrm{~kg}$.

The ERF method worked well at the Conqueror underground mine. Designed spans were achieved in all areas until the hangingwall broke back to the D5 structure in both the 2705/2706/2707 and 4001/4002/4003 areas.

In both cases, although there were large quantities of dilution, the majority of overbreak fell into areas that had already been bogged clean of ore. If not for this weak structure undulating in the hangingwall, the St Ives geotechnical department believes that the ERF values of greater than $20 \mathrm{~m}$ could have been attained.

\section{Acknowledgements}

I would like to thank present and previous mine management at the Leviathan underground mine and St Ives Gold mines for allowing the two authors to write this paper.

\section{References}

Barsanti, B.J. and Andrews, P.G. (2006) New stability assessment methods at the Conqueror mine, St Ives Gold Mine. Proceedings 7th Young Geotechnical Professionals Conference. Adelaide, Australia.

Barton, N., Lien, R. and Lunde, J. (1974) Engineering classification of rock masses for the design of tunnel support. Rock Mech., May, pp. 189-236.

Clark, L. and Pakalnis, R. (1997) An Empirical Design Approach for Estimating Unplanned Dilution from Open Stope Hangingwalls and Footwalls. Presented at the 99th AGM-CIM, Vancouver, p. 25.

International Society for Rock Mechanics (ISRM) (1981) Rock characterisation testing and monitoring. ISRM Suggested Methods, E.T. Brown (editor), Commission on Testing Methods, Pergamon Press, London, p. 211.

Mathews, K.E., Hoek, E., Wyllie, D.C. and Stewart, S.B.V. (1981) Prediction of stable excavations for mining at depth below 1000 metres in hard rock. CANMET Report DSS Serial No. OSQ80-00081, DSS File No. 17SQ.23440-09020, Ottawa, Dept. Energy, Mines and Resources, p. 39.

Milne, D.M., Pakalnis, R. and Lunder, P. (1996) Approach to the quantification of hangingwall behaviour. Transactions of the Institute Of Mining and Metallurgy, Vol. 105, A1-80, pp. A69-74. 
Milne, D.M. and Pakalnis, R. (1997) Theory behind empirical design techniques. Proceedings 12 th colloque en controle de terrain, Assoc. Min, Quebec.

Milne, D.M. (1997) Underground Design and Deformation based on surface geometry. PhD thesis, The University of British Columbia.

Nickson, S. (1992) Cable support guidelines for underground hard rock mine operations. Masters Thesis, University of British Columbia.

Pakalnis, R., Nickson, S., Lunder, P., Clark, L., Milne, D. and Mah, P. (1996) Empirical Methods for the Design of Mine Structures. Proceedings 11th colloque en controle de terrain, Assoc. Min, Quebec.

Potvin, Y., Hudyma, M.R. and Miller, H.D.S. (1989) Design guidelines for open stope support. CIM Bulletin, 82, (926), pp. 53-62. 
